\title{
Abnormality of Intracellular $5 \alpha$-Dihydrotestosterone Binding in Simple Hypospadias: Studies on Equilibrium Steroid Binding in Sonicates of Genital Skin Fibroblasts
}

\author{
BRUCE S. KEENAN, ${ }^{(25)}$ RONALD L. MCNEEL, AND EDMOND T. GONZALES \\ Departments of Pediatrics [B.S.K., R.L.M.] and Urology [E.T.G.], Baylor College of Medicine, \\ Houston, Texas, USA
}

Summary

A method was developed for the measurement of the binding of $\left[{ }^{3} \mathrm{H}\right] 5 \alpha$-dihydrotestosterone, $\left[{ }^{3} \mathrm{H}\right] \mathrm{DHT}$ and other steroids at equilibrium with intracellular androgen receptor of genital skin fibroblasts. This method utilized $0.2 \mathrm{M} \mathrm{Na}_{2} \mathrm{MoO}_{4}$ to stabilize the receptor and Sephadex G-25 chromatography to eliminate steroid metabolism. This binding protein showed the expected limited capacity, high affinity, and specificity of an androgen receptor.

Using this method, penile skin cultures from 26 infants with simple hypospadias (HS) were compared with 18 controls. The $\left[{ }^{3} \mathrm{H}\right] \mathrm{DHT}$ binding capacity $\left(\mathrm{B}_{\max }\right)$ was $10.1 \pm 1.3( \pm \mathrm{SE}) \mathrm{fmol} / \mathrm{mg}$ protein for controls and $6.1 \pm 1.7$ for HS. The two populations were significantly different by Mann-Whitney test $(P<0.001)$. Equilibrium dissociation constant was similar for both groups. Surprisingly, there was no correlation between $B_{\max }$ and the severity of the anatomic defect. $B_{\max }$ was below the values seen in HS for two of three infants with male pseudohermaphroditism. In complete androgen insensitivity, DHT binding was unmeasurable.

A subgroup exists in HS with an abnormality of intracellular androgen receptors. The lack of correlation between severity of hypospadias and $B_{\max }$ suggests that additional factors, such as differences in physicochemical properties of the receptor or factors present in utero, contribute to the development of HS.

\section{Abbreviation}

HS, simple hypospadias

HS, defined as incomplete fusion of the penile urethra without a urogenital sinus, is one of the more common birth defects. The overall incidence is estimated to be from one to eight per thousand live births $(8,10)$ whereas the more severe forms, with midshaft or perineal urethral orifices, have incidences reported as high as $0.2 \%$ (8). Furthermore, there appears to be a high familial incidence of $\mathrm{HS}$, ranging from $20-30 \%$ in different series $(4,9,22)$. In a recent survey of subjects with more severe anatomical defects, those with the genital configuration pseudovaginal perineoscrotal HS, familial defects in testicular steroidogenesis and in parameters of end organ responsiveness to androgens, $5 \alpha$-reductase and cytosol androgen receptor, were seen (16). It appears likely that familial defects in the above parameters might occur in simple HS as well. The present study was designed to assess one of those parameters, the fibroblast androgen receptor, as a possible etiologic factor.

\section{MATERIALS AND METHODS}

Subjects of the study. The experimental subjects, 26 infants and children with simple HS, were ages $111 / 12$ to $168 / 12 \mathrm{yr}$ with a median age of $211 / 12 \mathrm{yr}$. They were admitted to Texas Children's Hospital for evaluation and initial surgical repair of their defect. They were all in good health and were considered to have normal growth and development. No associated anomalies were detected on physical examination. Cryptorchidism was not present in any of the subjects.

The HS subjects were classified roughly according to the severity of their defects. In group I $(n=7)$ the urethral orifice was coronal or within $1 \mathrm{~cm}$ of the corona. In group II $(n=10)$ the orifice was $>1 \mathrm{~cm}$ from the corona and $<0.5 \mathrm{~cm}$ from the perineum. Group III $(n=10)$ consisted of subjects with perineal HS, but without a definite urogenital sinus. Penile length was considered normal in each case. Because of difficulties in assessing penile length in subjects with chordee (a common finding in hypospadias) length was only recorded in those instances where it was clearly below $3 \mathrm{~cm}$, the generally accepted lower limit. Intravenous pyelography was carried out on 16 subjects. Minor upper tract abnormalities were detected in three subjects, "minimal fullness of left pelvis," for example. Of the subjects not tested by to intravenous pyelography, four were of group I, four were of group II and one was of group III.

Male pseudohermaphroditism. Two sisters, ages $105 / 12$ and $165 / 12$, with complete androgen insensitivity were studied. They had normal female external genitalia, normal breast development, sparse pubic hair, abdominal testes, leukocyte karyotype $46 \mathrm{XY}$. Plasma testosterone concentrations were 162 and 858 $\mathrm{ng} / \mathrm{dl}$ for the $105 / 12-$ and $165 / 12$-yr-old sisters, respectively. Another subject, age $15 \mathrm{yr}$, with partial androgen insensitivity was also studied. He had severe hypospadias, failed to respond normally to exogenous testosterone (15), and had severe gynecomastia at puberty in association with a plasma testosterone concentration of $796 \mathrm{ng} / \mathrm{dl}$.

Genital skin samples were cultured from three infants with unclassified male pseudohermaphroditism. All three infants had ambiguous external genitalia with a small phallus, bilateral gonadal masses in the inguinal canal or scrotum and a $46 \mathrm{XY}$ karyotype: subject 1 had a bifid scrotum and a $2-\mathrm{cm}$ phallus with a urogenital sinus. After $10,000 \mathrm{U}$. intramuscular human chorionic gonadotrophin, given over $2 \mathrm{wk}$, plasma testosterone concentration was $1191 \mathrm{ng} / \mathrm{dl}$ (normal $>300$ ), plasma androstenedione was $165 \mathrm{ng} / \mathrm{dl}$ (normal $<200$ ). Urinary 17 -ketosteroids were normal $(<1 \mathrm{mg} / 24 \mathrm{~h})$. She was reared female. The testes were grossly and histologically normal. Subject 2 had a $2.6-\mathrm{cm}$ phallus with chordee. The scrotum was bifid. Testes were 
$1.8 \times 0.6$ and $1.6 \times 0.7 \mathrm{~cm}$. After $3000 \mathrm{U} \mathrm{HCG}$ in over $2 \mathrm{wk}$. plasma testosterone was $680 \mathrm{ng} / \mathrm{dl}$, androstenedione 136 , and $5 \alpha$-dihydrotestosterone was $136 \mathrm{ng} / \mathrm{dl}$. T/DHT ratio was 5 (nor$\mathrm{mal}<10$ ). This subject was reared male. Subject 3 had a $2-\mathrm{cm}$ phallus, inguinal testicular masses and a urogenital sinus. At age $5 \mathrm{~d}$ plasma testosterone was $42 \mathrm{ng} / \mathrm{dl}$. This subject was reared female. The testes were grossly and histologically normal.

After informed consent was obtained, skin was obtained near the median raphe along the shaft of the penis in HS subjects, at the time of the initial operative procedure, and fibroblast cultures established. Inguinal skin was also obtained from two subjects with complete androgen insensitivity at the time of orchiectomy and from the subject with partial androgen insensitivity. Foreskin was obtained from the three male pseudohermaphrodites at the time of removal of the phallus or of reconstructive surgery.

Controls. Foreskin was also obtained at the time of circumcision from 10 normal newborns, age $2-3 \mathrm{~d}$, and from eight normal children, ages 8 mo to $105 / 12$ yr.

Reagents were obtained as follows: media components for tissue culture from Grand Island Biological; Sephadex, G-25 and Dextran T-70 from Pharmacia; tris $\mathrm{HCl}$, reagent grade, testosterone, $5 \alpha$-dihydrotestosterone, androstenedione, and cortisol from Sigma; progesterone from Schwartz-Mann; Biofluor and methyltrienolone from New England Nuclear; activated charcoal (Norit A), benzene (HPLC grade), methanol (HPLC grade), chloroform (HPLC grade) and acetone (HPLC grade) from Fisher; ethanol (100\%) from National Biochemicals.

Tritium-labeled steroids were obtained from New England Nuclear. They were purified by chromatography on Sephadex LH-20 using the solvent system, benzene: methanol::95:5 and stored in ethanol before use. These were the following: $1,2,4,5,6,7,16,17-\left[{ }^{3} \mathrm{H}\right](\mathrm{N})-5 \alpha$-dehydrotestosterone, $200 \mathrm{Ci} /$ mmol; $17 \alpha$-methyl- $\left[{ }^{3} \mathrm{H}\right]$ methyltrienolone $(17 \beta$-hydroxy-17 $\alpha$ methyl-estra-4,9,11-trien-3-one, $\mathrm{MTr}$ ), $87 \mathrm{Ci} / \mathrm{mmol}$; and $1,2,6,7,16,17-\left[{ }^{3} \mathrm{H}\right](\mathrm{N})$-testosterone, $150 \mathrm{Ci} / \mathrm{mmol}\left[{ }^{3} \mathrm{H}-\mathrm{T}\right]$.

Cell culture. Skin explants were maintained in minimal essential medium with Earle's salts and $10 \%$ fetal bovine serum. Fibroblasts were grown in the same medium with $10 \%$ calf serum (14). Initial subcultures were frozen under liquid $\mathrm{N}_{2}$ in the latter medium containing $8 \%$ dimethylsulfoxide. These cultures were thawed as needed and grown up for assay. Recoveries of $50-70 \%$ were obtained from thawed cells. The cells studied were subcultured a total of 4-10 times before use and had been in continuous culture no more than $5 \mathrm{mo}$ at the time of assay. Previous studies have shown that androgen receptor levels in fibroblasts are stable during that period in culture (14)

Androgen receptor assay in fibroblast sonicates. For saturation analysis, fibroblast monolayers from six confluent $150 \times 15 \mathrm{~mm}$ plates per patient or control were used. Five patients with one quality control sample could be assayed simultaneously.

Culture medium was aspirated and the monolayers washed once with Hank's balanced salt solution and once with $0.02 \mathrm{M}$ Tris- $\mathrm{HCL}(\mathrm{pH} 7.4$ ) containing $1.5 \mathrm{mM}$ disodium EDTA and $0.15 \mathrm{M} \mathrm{KCL}$ (TEK.15) at room temperature. Then, two washes were carried out with TEK. 15 at $4^{\circ} \mathrm{C}$. All subsequent steps were performed at $0-4^{\circ} \mathrm{C}$. The monolayers were detached in TEK.15 with a teflon policeman and centrifuged at $1000 \mathrm{~g}$ for $10 \mathrm{~min}$ and the supernatant discarded. The pellets were combined, sonicated by submersion in a tube (14) in $0.5-1 \mathrm{ml}$ of $0.02 \mathrm{M}$ TrisHCL (pH 7.4) containing $1.5 \mathrm{mM}$ disodium EDTA, $1 \mathrm{mM} 2-$ mercaptoethanol, and $0.2 \mathrm{M}$ sodium molybdate, and centrifuged at $20,000 \mathrm{~g}$ for $20 \mathrm{~min}$. The resulting supernatant was applied to a Sephadex G-25 column $(1.5 \times 18.0 \mathrm{~cm})$ and the void volume collected. This step was necessary to prevent steroid metabolism in the incubation mixture, presumably by removing cofactors necessary for steroid oxido-reductase activity.

Aliquots $(0.2 \mathrm{ml})$ of the void volume were incubated in duplicate with $0.05 \mathrm{ml}$ of $\left[{ }^{3} \mathrm{H}\right] \mathrm{DHT},\left[{ }^{3} \mathrm{H}\right] \mathrm{T}$, or $\left[{ }^{3} \mathrm{H}\right] \mathrm{MeTr}$ at concentration ranges of $0.25-5 \mathrm{nM}$ (in TEMMo), making the final concentration range $0.05-2.5 \mathrm{nM}$. Also, aliquots $(0.2 \mathrm{ml})$ of the void volume were incubated with $\left[{ }^{3} \mathrm{H}\right] \mathrm{DHT},\left[{ }^{3} \mathrm{H}\right] \mathrm{T}$, or $\left[{ }^{3} \mathrm{H}\right] \mathrm{MeTr}$ containing 100 -fold excess of the corresponding nonradioactive steroid to estimate for $\mathrm{B}_{\mathrm{N}}(14)$. Saturable binding or $\mathrm{Bs}$ was calculated by the formula $\mathrm{Bs}_{\mathrm{S}}=\mathrm{B}_{\Upsilon}-\mathrm{B}_{\mathrm{N}}$, where $\mathrm{B}_{\Upsilon}$ is the total bound steroid at a given concentration (Fig. 1). Protein was measured from an aliquot $(0.2 \mathrm{ml})$ of the void volume by the method of Lowry et al. (17). The assay tubes were thoroughly mixed and incubated at $4^{\circ} \mathrm{C}$ for $18 \mathrm{~h}$. Unbound steroid was separated by adding $0.5 \mathrm{ml}$ of a suspension of $1 \%$ activated charcoal and $0.05 \%$ Dextran $\Upsilon-70$ in $0.02 \mathrm{M}$ Tris-HCL (pH 7.4) and $1.5 \mathrm{mM}$ disodium EDTA (TE buffer) to each assay tube, at $0^{\circ} \mathrm{C}$. The contents of the tubes were mixed, incubated for $15 \mathrm{~min}$ at $0^{\circ} \mathrm{C}$, and centrifuged at $2000 \mathrm{~g}$ for $10 \mathrm{~min}$. To measure bound radioactivity, an aliquot $(0.5 \mathrm{ml})$ of the supernatant was combined with $10 \mathrm{ml}$ Biofluor in a $20 \mathrm{ml}$ counting vial and counted in a Packard 2650 liquid scintillation counter. Quench correction was made by the external standard method to obtain dis/min. From the dis/min and the known specific activity of the labeled steroids, the mass of specifically bound steroid could be estimated in fmol. Data were analyzed by Scatchard analysis (20). The slope and intercepts of the Scatchard plot, (Bs/U vs Bs) were determined by linear regression, using the least squares method. The results for binding capacity $\left(\mathrm{B}_{\max }\right)$ were expressed as $\mathrm{fmol} /$
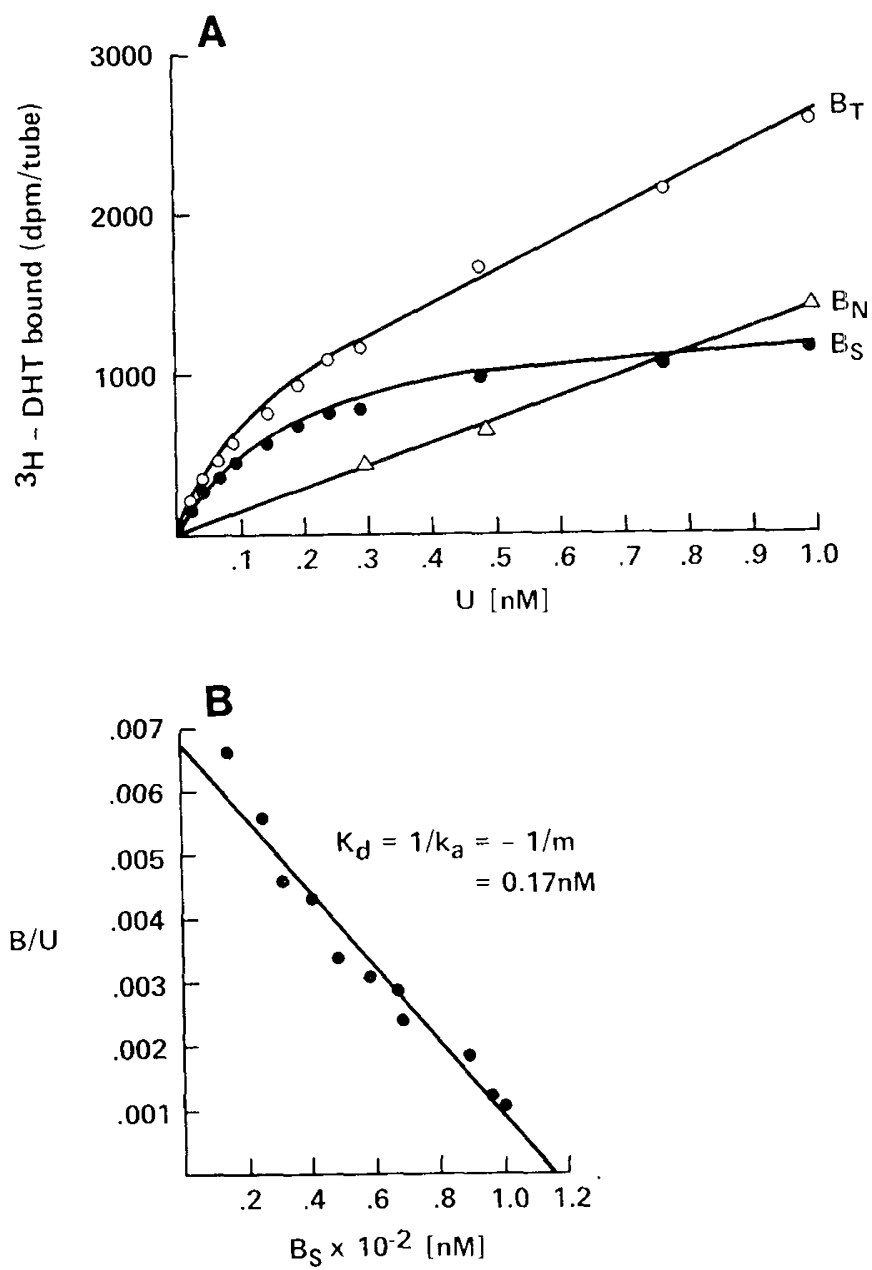

Fig. 1. Saturation analysis of $\left[{ }^{3} \mathrm{H}\right] \mathrm{DHT}$ binding in a sonicate of normal foreskin fibroblasts after Sephadex-G25 chromatography. (A) Michaelis-Menten plot. $\mathrm{B}_{\mathrm{T}}$, total bound $\left[{ }^{3} \mathrm{H}\right] \mathrm{DHT}$ : $\mathrm{B}_{\mathrm{N}}$, nonspecific binding. i.e., $\left[{ }^{3} \mathrm{H}\right] \mathrm{DHT}$ bound in the presence of $200 \mathrm{nM}$ unlabeled DHT, and Bs, specifically or saturable bound $\left[{ }^{3} \mathrm{H}\right] \mathrm{DHT}\left(\mathrm{M} \times 10^{-9}\right) . \mathrm{Bs}=\mathrm{B}_{\mathrm{T}}-$ $\mathrm{B}_{\mathrm{N}}$. (B) Scatchard plot of saturable bound $\left[{ }^{3} \mathrm{H}\right] \mathrm{DHT}$, same primary data as in $(A)$. Each point is the average of two determinations. $U$, unbound $\left[{ }^{3} \mathrm{H}\right] \mathrm{DHT}\left(\mathrm{M} \times 10^{-9}\right)$. 
$\mathrm{mg}$ protein and the dissociation constant $\left(\mathrm{K}_{\mathrm{d}}=1 / \mathrm{Ka}=-1 /\right.$ slope) as $\mathrm{M} \times 10^{-9}$.

Equilibrium was apparently achieved in this assay. Maximal binding occurred about $4 \mathrm{~h}$ after addition of tracer, and this level was stable for $48 \mathrm{~h}$. In addition, there was no detectable metabolism of tracer, as described below.

Stability of steroids in the receptor assay mixture was demonstrated by determining radiochemical purity. $\left[{ }^{3} \mathrm{H}\right] \mathrm{DHT},\left[{ }^{3} \mathrm{H}\right] \mathrm{T}$, or $\left[{ }^{3} \mathrm{H}\right] \mathrm{MTr}(2-6 \mathrm{nM})$ was incubated overnight at $4^{\circ}$ with the void volume fraction of the Sephadex G-25 eluate of fibroblast sonicates. These mixtures were extracted with 20 vol dichloromethane, and chromatography carried out on silica gel thin layer plates with the solvent system, chloroform:acetone::90:10 (v/v). The entire chromatogram was eluted in segments and counted. More than $95 \%$ of the tracer from each incubation cochromatographed with the authentic standard corresponding to the steroid added at the beginning. No additional peaks were seen; thus, steroid metabolism was prevented by the gel filtration step.

Taking into account the efficiency of washing the fibroblast monolayers and the binding activity of the serum, the possible contribution of the proteins in fetal calf serum to the measurement of Bs is about 1 dis/min per assay point in which Bs was $2876 \mathrm{dis} / \mathrm{min}$

Stability of the androgen receptor was tested as follows: cells were sonicated in TE buffer. After centrifugation at $20,000 \mathrm{~g}, 20$ min $4^{\circ} \mathrm{C}$, the supernatant was divided into two parts: to half was added $\mathrm{Na}_{2} \mathrm{MoO}_{4}$ and 2-mercaptoethanol to yield final concentrations of $0.2 \mathrm{M}$ and $1.0 \mathrm{mM}$, respectively and to the other half an equal volume of TE buffer. Two nanomolar $\left[{ }^{3} \mathrm{H}\right] \mathrm{DHT}$ with or without a 100 -fold excess of unlabeled DHT was added at times $0,1,2,4,8$, and $24 \mathrm{~h}$. Incubation was carried out at $4^{\circ} \mathrm{C}$ before and after addition of $\left[{ }^{3} \mathrm{H}\right] \mathrm{DHT}$. Dextran-coated charcoal was added $16-24 \mathrm{~h}$ after the addition of $\left[{ }^{3} \mathrm{H}\right] \mathrm{DHT}$ in order to separate unbound from bound radioactivity, determined as described above. When plotted semilogarythmically the data indicated a loss of activity of $25 \%$ per $h$ in TE and $10 \%$ per $\mathrm{h}$ in TEMMo (in a pilot study of fibroblast sonicates, about $15 \%$ more saturable $\left[{ }^{3} \mathrm{H}\right] \mathrm{DHT}$ binding was seen with $0.2 \mathrm{M}$ than with $0.1 \mathrm{M} \mathrm{Na}_{2} \mathrm{MoO}_{4}$ ). Our previous experience (14) indicated that the steroid-receptor complex, once formed, was stable at $0-4^{\circ} \mathrm{C}$ for $48 \mathrm{~h}$. In the method used for the present studies, about 30 min clapsed between sonication and the beginning of the incubation, and about $4 \mathrm{~h}$ was required to reach equilibrium; thus, cquilibrium measurements were possible with only modest losses of binding activity.

Inhibitory constants for a number of possible ligands were determined as follows: saturation curves for $\left[{ }^{3} \mathrm{H}\right] \mathrm{DHT}$ in the Sephadex G-25 void volume fraction were carried out in the absence and in the presence of unlabeled competitors. The concentrations of these competitors were sufficient to effect a $30-50 \%$ reduction in binding. By comparing the slopes of the Scatchard plots for $\left[{ }^{3} \mathrm{H}\right] \mathrm{DHT}$ alone or with added competitor, $\mathrm{K}_{\mathrm{i}}$ for the competitor was determined (21).

\section{RESULTS}

DHT-binding bl androgen receptors in control sonicates. The androgen receptor in skin fibroblast sonicates was saturated at about $1 \mathrm{nM}$ DHT (Fig. 1), thus the range $0.05-1.0 \mathrm{nM}$ was used for routine assays. Scatchard analysis of the data from 18 control cultures gave a $\mathrm{K}_{\mathrm{d}}$ of $0.28 \pm 0.04 \mathrm{nM}( \pm \mathrm{SE})$, range $0.15-0.65$ $\mathrm{nM}$. $\mathrm{B}_{\max }$ for controls was $10.1 \pm 1.3 \mathrm{fmol} / \mathrm{mg}$ protein. Based upon an average protein content of $438 \mu \mathrm{g}$ protein per $10^{6}$ cells, the number of receptor binding sites per cell averaged 2663.

The specificity of the binding reaction was assessed in two ways. First, saturation analysis was carried out using labeled derivatives of two naturally occurring androgens, $\left[{ }^{3} \mathrm{H}\right] \mathrm{DHT}$ and $\left[{ }^{3} \mathrm{H}\right] \mathrm{T}$. as well as the potent synthetic androgen $\left[{ }^{3} \mathrm{H}\right] \mathrm{MTr}$. In paired studies, in the same batches of sonicate, $\mathrm{B}_{\max }$ values were similar for $\left[{ }^{3} \mathrm{H}\right]$ DHT and $\left[{ }^{3} \mathrm{H}\right] \mathrm{T}$ as well as for $\left[{ }^{3} \mathrm{H}\right] \mathrm{DHT}$ and $\left[{ }^{3} \mathrm{H}\right]$ MTr (Table 1). In a separate set of experiments, competition
Table 1. Specificity of androgen binding in skin fibroblasts

\begin{tabular}{|c|c|c|c|}
\hline Ligand & $\begin{array}{c}\mathrm{K}_{\mathrm{d}} \\
(\mathrm{nM})\end{array}$ & $\begin{array}{c}\mathrm{B}_{\max } \\
(\mathrm{fmol} / \mathrm{mg} \\
\text { protein })\end{array}$ & $\begin{array}{c}\mathrm{K}_{\mathrm{i}}{ }^{*} \\
(\mathrm{nM})\end{array}$ \\
\hline $5 \alpha$-dihydrotestosterone & $0.15-0.65$ & $10.3-14.7$ & 0.10 \\
\hline Methyltrienolone & $0.25-0.54$ & 12.5 & 0.11 \\
\hline Testosterone & 2.7 & 17.1 & 0.94 \\
\hline Progesterone & $\ldots$ & $\ldots$ & 3.28 \\
\hline Androstenedione & $\ldots$ & $\ldots$ & 7.8 \\
\hline Cortisol & $\ldots$ & $\ldots$ & 1500 \\
\hline
\end{tabular}

${ }^{*} K_{i}$ determined from the slope of Scatchard plot $(m)$ of $\left[{ }^{3} \mathrm{H}\right] \mathrm{DHT}$ saturation in the presence of unlabeled inhibitor (ligand):

$$
\mathrm{m}=\frac{-\mathrm{K}_{\mathrm{d}}}{\mathrm{K}_{\mathrm{i}}(\mathrm{l})+1}
$$

Where $\mathrm{K}_{\mathrm{d}}=$ dissociation constant with $\left[{ }^{3} \mathrm{H}\right] \mathrm{DHT}$ alone and $(\mathrm{I})=$ concentration of inhibitor (at least $97 \%$ of the radioactivity was unbound under these experimental conditions).

between $\left[{ }^{3} \mathrm{H}\right] \mathrm{DHT}$ and a variety of unlabeled steroids was assessed by performing $\left[{ }^{3} \mathrm{H}\right] \mathrm{DHT}$ saturation analysis in the absence or presence of a known concentration of competitor. $\mathrm{K}_{i}$, which is inversely related to affinity of a steroid for the receptor, was determined from the slope of the Scatchard plot in the presence of inhibitor and the $\mathrm{K}_{\mathrm{d}}$ of the $\left[{ }^{3} \mathrm{H}\right] \mathrm{DHT}$-receptor reaction in the absence of inhibitor (Table 1). DHT and MTr gave similar values for $\mathrm{K}_{\mathrm{d}}, \mathrm{B}_{\max }$ and $\mathrm{K}_{\mathrm{i}}$, suggesting that they were bound to the same low capacity binding moiety and with similar affinities. T binding was significantly weaker than was DHT or MTr. All three steroids appeared to be mutually competitive. The high degree of specificity of the receptor was suggested by the high $\mathrm{K}_{\mathrm{i}}$ values for progesterone, androstenedione, and cortisol.

DHT binding in sonicates of IIS fibroblasts. In sonicates from HS fibroblasts, $B_{\max }$ was $6.1 \pm 0.7( \pm \mathrm{SE})(n=27)$. Although there was considerable overlap between the two groups, the distribution of $B_{\max }$ for $\left[{ }^{3} \mathrm{H}\right] \mathrm{DHT}$ binding in sonicates of $\mathrm{HS}$ cultures was shifted toward lower values (Fig. 2B), with respect to controls $\left(\mathrm{B}_{\max }=10.1 \pm 1.3\right)$. This difference was significant by the Mann-Whitney test, $P<0.001$. There was no detectable difference between the two groups regarding $\mathrm{K}_{\mathrm{d}}$ : controls were $0.28 \pm 0.04 \mathrm{nM}$ and HS $0.25 \pm 0.04$. The control samples from newborn and older subjects were not detectably different as regards $B_{\max }$ or $K_{d}$. No relationship was apparent between the severity of HS and the number of receptor sites $\left(B_{\max }\right)$. As seen in Figure $2 \mathrm{~A}$, there were similar numbers of subjects with mild, moderate, and severe defects within the lowest interval of $B_{\max }$.

In addition, fibroblasts from controls and HS subjects were compared with more severe forms of male pseudohermaphroditism (Fig. 3). This was done as a means of comparing the results of the equilibrium measurements used in the present study with previous work in the intact monolayers. Genital skin fibroblasts from two of three subjects with unclassified male pseudohermaphroditism, whose genital anatomy was consistent with the syndrome pseudovaginal perineoscrotal hypospadias, had extremely low values for DHT-receptor binding $\left(\mathrm{B}_{\max }\right)$. As expected, two cultures from subjects with complete androgen insensitivity had undetectable levels of DHT-binding, and one subject with previously documented partial androgen insensitivity (15) had a low normal value. When a broader spectrum of defects was considered, a rough correlation was seen between severity of the genital defect and the decrease in receptor number.

\section{DISCUSSION}

DHT-binding activity in sonicates of genital skin fibroblasts has kinetic properties and genetic variations similar to the androgen receptor previously described in intact fibroblast monolayers (13-15) for both. It is a high affinity, low capacity system; the binding reaction has a high degree of stereospecificity. The 

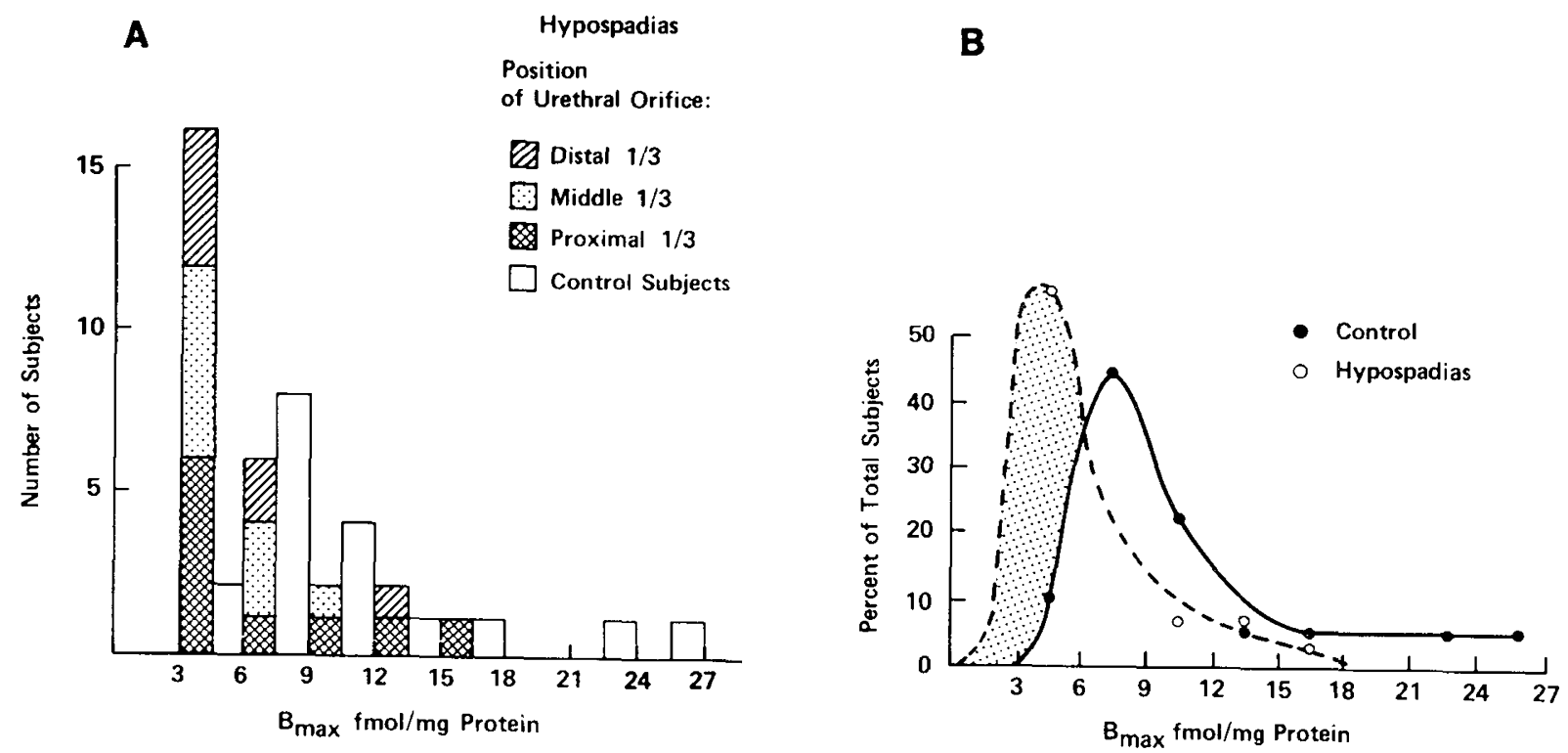

Fig. 2. Histogram of $\left[{ }^{3} \mathrm{H}\right] \mathrm{DHT}$ binding capacity $\left(\mathrm{B}_{\max }\right)$ in fibroblast sonicates from control and hypospadias subjects. (1) The numbers of individuals within each interval are compared. $(B)$ The percentage of subjects relative to the total in each of the two groups is comparcd for cach interval.

A GENITAL SKIN

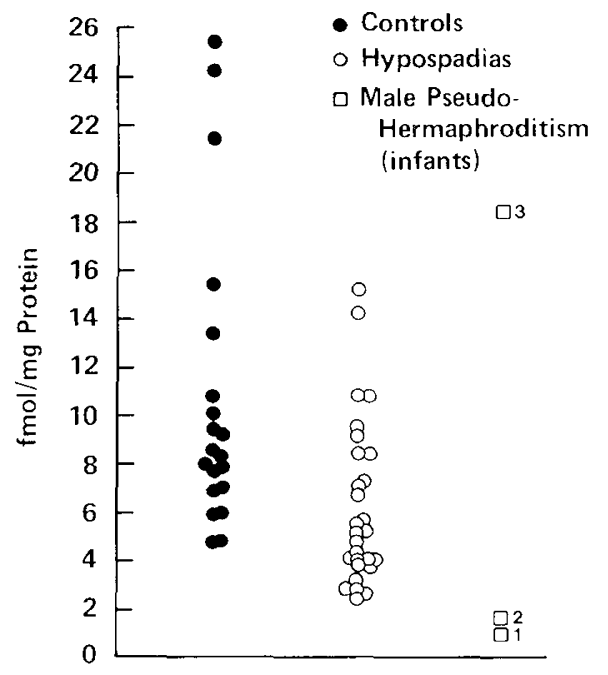

B INGUINAL SKIN

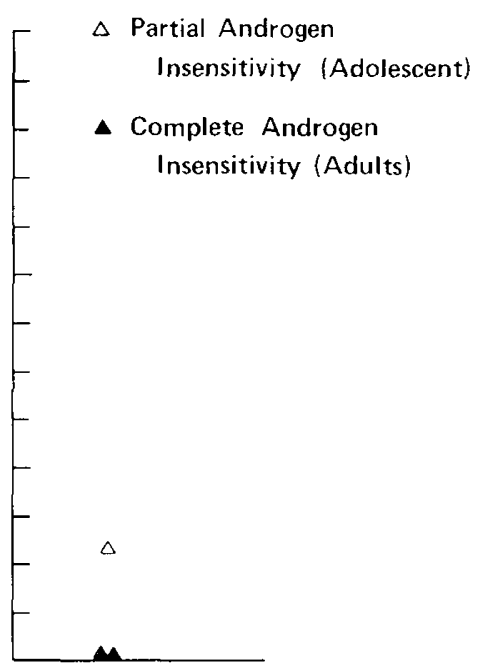

Fig. 3. Comparison of $\left[{ }^{3} \mathrm{H}\right]$ DHT binding capacity in fibroblast sonicates from control, hypospadias and male pseudohermaphroditic subjects. $(A)$ Comparision between cultures of genital skin fibroblasts. $(B)$ Inguinal skin fibroblasts.

number of binding sites per cell, average 2663 , determined in this preparation was consistent with our previous measurements in intact monolayers (14). Saturable DHT-binding was undetectable in fibroblasts from subjects with complete androgen insensitivity and showed markedly reduced values in male pseudohermaphroditism and in partial androgen insensitivity. The values of $\mathrm{K}_{d}$ for $\left[{ }^{3} \mathrm{H}\right] \mathrm{DHT}$ and for $\left[{ }^{3} \mathrm{H}\right] \mathrm{MT}$ r subjects were similar to values reported for prostate androgen receptor in rats (24) and for human skin cytosol $(18)$. The fact that $\left[{ }^{3} \mathrm{H}\right] \mathrm{DHT}$ and $\left[{ }^{3} \mathrm{H}\right]$ MTr bound to a similar number of sites and with a similar affinity excludes serum proteins in the culture media as a significant contributor to the measurements made $(5,6)$.

Whereas $\mathrm{K}_{d}$ for controls was lower in the present study than we had previously demonstrated in intact fibroblast monolayers (14), steroid metabolism during incubation, which would tend to increase the apparent $K_{d}$, was eliminated by Sephadex G-25 chromatography. $B_{\max }$ values for controls were within the range reported previously in fibroblast monolayers (14), though in the lower part of that range. These lower values may be explained in part by instability of the uncomplexed receptor in vitro.

Fibroblast sonicates from HS subjects had a lower mean number of receptor binding sites than did controls. This indicates that an abnormality of androgen receptor function may be an etiologic factor in this common birth defect. These results are similar to those of Svensson and Snokowski (23) who showed decreased saturable MTr binding in preputial skin homogenates of HS subjects; however, the apparent $\mathrm{K}_{d} \mathrm{~s}$ for DHT and MTr binding, obtained by those investigators, were higher than were observed in the present study or in studies of prostate androgen receptors (24). The reasons for higher $\mathrm{K}_{\delta} \mathrm{s}$ in whole skin homogenates are not readily apparent but may have been due to endogenous steroids in the tissue samples or to changes in the receptor's properties during sample preparation.

The overlap in values of $\mathrm{B}_{\max }$ for DHT between HS and control 
subjects may be explained by multiple etiologies for the syndrome. In more severe forms of $\mathrm{HS}$, such as pseudovaginal perineoscrotal hypospadias, genetic heterogeneity exists (16), including a variety of heritable testicular and end-organ defects, and the same is probably true of simple HS. A decreased number of androgen receptors in HS implies some degree of androgen insensitivity, but it is not known whether clinical evidence of androgen insensitivity exists in this population. In order to clinically document androgen insensitivity one must show that the subject's response to a known plasma testosterone was insufficient or absent. Such a determination must be made in postpubertal individuals by correlating genital anatomy with indices of androgen responsiveness, such as spermatogenesis, plasma concentrations of testosterone, LH and FSH and fibroblast androgen receptor assays. Alternatively a short course of testosterone therapy might give the desired correlation. But the sensitivity and precision of such a study is not known at present. It will be important in future studies to make such correlations, so that the predictive value of measuring fibroblast androgen receptors may be ascertained.

An unexpected finding in this study was the lack of correlation between the severity of HS and the level of DHT-binding. This suggests that the number of receptor molecules per cell is not the sole determinant of defective androgen action in such a patient. A similar discrepancy was noted by Aiman et al. (1) in a study of male pseudohermaphroditism. In that study, similar levels of DHT-binding were observed in subjects with complete, "incomplete" and "partial" androgen insensitivity.

Two of the three male pseudohermaphrodites in this study demonstrated very low values for $B_{\max }$. This suggested the possibility of partial androgen insensitivity. Indeed, some element of androgen resistance is likely in those cases. Because a number of subjects with mild $\mathrm{HS}$ had low values for $\mathrm{B}_{\max }$, caution is advised in predicting these subjects' responses to testosterone during puberty.

A number of other interpretations of our findings are possible. Variability of sampling related to selection of a skin biopsy site and selective growth of a given population of fibroblasts from an explant of skin could contribute to overlap between groups. The decrease in receptor number in a given HS subject might reflect either a decreased number of binding sites or relative instability of the receptor or the steroid-receptor complex. Apparent receptor instability has been reported in male pseudohermaphroditism $(12,19)$. Clearly, the androgen receptor is moderately unstable under the present assay conditions, at least until equilibrium between receptor and steroid is reached. Elucidation of these questions will require further study.

Receptor instability implies a defect in receptor structure. One parameter that might reflect a structural defect, $K_{d}$, was normal in hypospadias in our study, in that of Svensson (23), and in most instances of male pseudohermaphroditism $(2,3,11,13)$. Recently, Brown et al. (7) have demonstrated consistent, but relatively small differences in the physicochemical properties of the androgen receptor in receptor-positive subjects with complete androgen insensitivity. These included an approximately 3-fold difference in $\mathrm{K}_{\mathrm{d}}$, increased thermolability both in vitro and in the intact monolayer, and quantitative differences in the stereospecificity of the binding reaction. Whereas those differences may not in themselves account for the degree of androgen insensitivity, they may serve as a marker for an abnormal receptor. A defective receptor might also be expected to interact with nuclear chromatin in a defective manner. Further study of the physicochemical properties of the androgen receptor and the interaction of the steroid-receptor complex with nuclear chromatin may, in the future, elucidate the defect or defects involved in the pathogenesis of HS.

In conclusion, it appears that there is a subgroup of HS subjects in which some defect of the androgen receptor exists in genital skin fibroblasts. The nature of this defect is not yet defined.
Additional studies must be performed to determine whether androgen insensitivity exists postnatally in these subjects.

\section{REFERENCES AND NOTES}

1. Aiman, J., Griffin. J. E., Gazak . J. M., Wilson, J. D., and MacDonald, P. C. Androgen insensitivity as a causc of infertility in otherwise normal men. $\mathrm{N}$ Engl. J. Med., 300: 223 (1979).

2. Amrhein, J. A., Meyer. W. J.. Jones, H. W.. and Migeon, C. J.: Androgen insensitivity in man: evidence for genetic heterogeneity. Proc. Natl. Acad. Sci. USA. 73: 891 (1976)

3. Amrhein, J. A., Jones-Klingensmith, G.. Walsh, P. C., McKusick, V. A., and Migeon, C. J.: Partial androgen insensitivity: the Reifenstein syndrome revisited. N. Engl. J. Med., 297: 350 (1977).

4. Bauer. S. B.. Retik, A. B., and Colodny, A. H.: Genetic aspects of hypospadias. Urol. Clin. N. Am., 8: 559 (1981).

5. Bonne, C. and Raynaud, J-P.: Methyltrienolone, a specific ligand for cellular androgen receptors. Steroids, 26: 227 (1975).

6. Bonne. C. and Raynaud, J-P.: Assay of androgen binding sites by exchange with methyltricnolone (R1881). Steroids, 27: 497 (1976).

7. Brown, T. R., Maes, M., Rothwell, S. W., and Migeon, C. J.: Human complete androgen insensitivity with normal dihydrotestosterone receptor binding capacity in cultured genital skin fibroblasts: evidence for a qualitative abnormality of the receptor. J. Clin. Endocrinol. Metab., 55: 61 (1982).

8. Carter, C. O.: Multifactorial genetic disease. In: V. S. McKusick and R. Claiborne: Medical Genetics. p. 199 (New York HP Publishing. 1973).

9. Chen, Y. C. and Wooley, P. C.: Genetic studies on hypospadias in males. J. Med. Genet., 8: 153 (1971).

10. Editorial: Genetics of Hypospadias. Brit. Med. J.. 4: 189 (1972).

11. Griffin. J. E. and Wilson, J. D.: Studies on the pathogenesis of the incomplete forms of androgen resistance in man. J. Clin. Endocrinol. Metab., 45: 1137 (1977).

12. Griffin, J. E.: Testicular feminization associated with a thermolabile androgen receptor in cultured human fibroblasts. J. Clin. Invest., 64: 1624 (1979).

13. Keenan. B. S., Meyer, W. J., Hadjian, A. J., Jones, H. W.. and Migeon, C. J. Syndrome of androgen insensitivity in man: absence of $5 \alpha$-dihydrotestosterone binding protein in skin fibroblasts. J. Clin. Endocrinol. Metab., 38: 1143 (1974).

14. Keenan. B. S., Meyer. W. J.. Hadjian. A. J.. and Migeon, C. J.: Androgen receptor in human skin fibroblasts: characterization of a specific $17-\beta-$ hydroxy-5 $\alpha$ androstane-3-one-protein complex in cell sonicates and nuclei. Steroids, 25: 535 (1975)

15. Keenan, B. S.. Kirkland, J. L.. Kirkland, R. T., and Clayton. G. W.: Male pseudohermaphroditism with partial androgen insensitivity. Pcdiatrics. 59 224 (1977).

16. Keenan, B. S.: Pseudovaginal perineoscrotal hypospadias, genetic heterogeneity. Urol. Clin. N.A.. 7: 393(1980).

17. Lowry, O. H., Rosebrough. N. J.. Farr, A. L., and Randall, R.: Protein measurement with the Folin phenol reagent. J. Biol. Chem., I93: 265 (195I).

18. Mowszowicz. I.. Mohamed. R.. Wright. F.. Bouchard, B., Kuttenn. F., and Mauvais-Jarvis. P.: Androgen receptors in human skin cytosol. J. Clin. Endocrinol. Metab., 52: 338 (1981).

19. Pinsky, L., Kaufman. M., and Summitt. R. L.: Congenital androgen insensitivity due to a qualitatively abnormal androgen receptor. Am. J. Med. Genet. 10: 91 (1981).

20. Scatchard, G.: The attraction of proteins for small molecules and ions. Ann. N. Y. Acad. Sci., 5l:660 (1949).

21. Shain. S. A. and Boesel, R. W.: Saturation analysis of the binding of androgens. antiandrogens and estrogens by the cytoplasmic high affinity androgen receptor of the rat ventral prostate. J. Steroid Biochem.. 6: 43 (1975).

22. Sorensen. H. R.: Hypospadias With Special References to Etiology. (Munksgaard. Copenhagen, 1953).

23. Svensson. J. and Snochowski, M.: Androgen receptor levels in preputial skin from boys with hypospadias. J. Clin. Endocrinol. Metab., 49: 340 (1979).

24. Wilson. E. M. and French. F. S.: Binding properties of androgen receptors. evidence for identical receptors in rat testis, epididymis and prostate. J. Biol. Chem.. 251: 4620 (1976).

25. Requests for reprints should be addressed to: Dr. Bruce $S$. Keenan, Department of Pediatrics, 1200 Moursund Avenue. Houston. Texas 77030.

26. This work was supported by the following: The Arland B. Coleman Pediatric Urology Fund. The National Foundation. March of Dimes Grant \#6-187. The Department of Health and Human Resources Clinical Research Center Grant M01RR00188, research grant HD15018, and NIH Grant HD15018.

27. The authors wish to express their appreciation to George W. Clayton, M.D. for his encouragement and support in this work. to Donald J. Tindall. Ph.D. Department of Cell Biology, Baylor College of Medicine, for his helpfu] comments on the manuscript, and to Jeannette Gottsch for her assistance in the preparation of this manuscript.

28. We wish to thank the following physicians who contributed male pseudohermaphroditic subjects to this study: Dr. Raphael L. Bejar, Variety Children's Hospital. Miami, Florida; Dr. L. Russell Malinak. Department of Obstetrics and Gynecology, Baylor College of Medicine, Houston, Texas; Dr. Robert P. Schwartz, Department of Pediatrics. Charlotte Memorial Hospital, Charlotte. N.C.: and Dr. J. Rodman Seely, Department of Pediatrics. University of Oklahoma, Oklahoma City, Ok. 